\title{
Flour fortification for nutritional and health improvement: A review
}

\author{
Rossana V.C. Cardoso ${ }^{\mathrm{a}, \mathrm{b}}$, Ângela Fernandes ${ }^{\mathrm{a}}$, Ana M. Gonzaléz-Paramás ${ }^{\mathrm{b}}$, Lillian Barros ${ }^{\mathrm{a}}$, \\ Isabel C.F.R. Ferreira ${ }^{\mathrm{a}, *}$ \\ ${ }^{a}$ Centro de Investigação de Montanha (CIMO), Instituto Politécnico de Bragança, Campus de Santa Apolónia, 5300-253 Bragança, Portugal \\ ${ }^{\mathrm{b}}$ Grupo de Investigación en Polifenoles (GIP), Unidad de Nutrición y Bromatología, Facultad de Farmacia, Universidad de Salamanca, Campus Miguel de Unamuno, E- \\ 37007 Salamanca, Spain
}

\section{A R T I C L E I N F O}

\section{Keywords:}

Flours

Fortification

Micronutrients

Health benefits

\begin{abstract}
A B S T R A C T
Deficiencies of micronutrients, essentially vitamins and minerals, have mainly cause several illnesses, especially in children and women worldwide. Governments and world organizations have focused great efforts to address these shortcomings and improve the health of the populations. This malnutrition can be combated by fortifying basic foods that are consumed daily. Thus, flours, especially wheat, maize and rice, are a popular and common food in the world's populations diet and are gaining considerable attention as a suitable vehicle for micronutrient fortification. There are some studies that show the effectiveness of flour fortification in combating micronutrient deficiencies and several diseases and the flour fortification strategies are directed to meet nutritional and health needs of the populations. The main points discussed in this review are food fortification, with great focus in flour fortification, health benefits, and legislative issues. This review also highlights multifaceted issues related to flour fortification to meet nutritional needs and to improve the health of vulnerable populations.
\end{abstract}

\section{Introduction}

Vitamins and minerals are essential elements for the growth, metabolism and maintenance of a healthy body and deficiencies of these nutrients have resulted in irreversible physical and cognitive consequences, since these compounds play an important role in the normal functioning of almost all organs (Looman et al., 2019; Wahengbam, Das, Green, Shooter, \& Hazarika, 2019). The FAO, IFAD, UNICEF, WFP, and WHO (2018) have estimated that billions of people are deficient in different types of vitamins and minerals. Revealing that in several countries, women and children suffer from severe deficiencies caused by inadequate amounts of vitamins, amino acids and minerals, more precisely vitamin A, vitamin D, iron, zinc and probably other micronutrients. It has also been reported that several micronutrient deficiencies cohabit and are more prevalent in developing countries (Black et al., 2013; Blumfield, Hure, Macdonald-wicks, Smith, \& Collins, 2013; Farhat, Lees, Macdonald-Clarke, \& Amirabdollahian, 2019; Radziejewska \& Chmurzynska, 2019; Ramakrishnan, 2002). A study in pregnant Nepalese women showed vitamin B6 deficiency and in villages in India showed zinc, iron and folate deficiency (Jiang, Christian, Khatry, Wu, \& West, 2005; Pathak, Kapoor, Saxena, Kumar, \& Gupta, 2004). Moreover, according to WHO, millions of pre-school children worldwide and pregnant women suffer from vitamin A deficiency
(WHO, 2009); otherwise, it is also estimated that, globally, about million people are affected by iodine deficiency (Li \& Eastman, 2012).

Micronutrient deficiencies can lead to unfavourable health consequences, such as growth problems, immune competence, mental and physical development, and poor reproductive outcomes. It has also been reported to be related to an increased occurrence, severity and mortality of infectious diseases such as malaria, diarrhoea, pneumonia, among others. These deficiencies have numerous unfavourable results across all populations and age groups, with children and women of reproductive age being more vulnerable (Black et al., 2013; Gibson \& Hotz, 2002; Looman et al., 2019).

Many strategies have been used to combat micronutrient deficiencies, such as exclusive breastfeeding during babies first 6 months, control of parasitic infections, food fortification, food diversification, and nutritional supplementation (Black et al., 2013; Hemery et al., 2018; WHO, 2000). Particularly, fortification is a method of incorporating nutrients or non-nutritive bioactive components into food products (Dwyer et al., 2015). Food fortification is one of the methods that has been applied increasingly and addressed to all age groups, being widely used to minimize micronutrient deficiency. By placing micronutrients in food products consumed daily, it reaches target populations, from which daily dietary requirements of micronutrients are scarcely satisfied (WHO \& FAO, 2006). It is an impressive public health

\footnotetext{
* Corresponding author.

E-mail address: iferreira@ipb.pt (I.C.F.R. Ferreira).
} 
strategy with interesting cost-effectiveness ratios and has the advantage of being installed in the usual dietary patterns, without a major change in eating or health practices and is generally well accepted by the populations (Berner, Keast, Bailey, \& Dwyer, 2014; WHO \& FAO, 2006).

The development of new products has a strategic role in the food industry, because consumers are increasingly demanding food products with high nutritional value that provide health benefits (PáramoCalderón et al., 2019). As a staple food common in many countries, flour is often considered one of the most suitable vehicles for multimicronutrient fortification (Hemery et al., 2018). In addition, fortified flours can be a major source of bioactive compounds, since flour can be fortified with many micronutrients, reducing the risk of multiple deficiencies where they exist and improve health benefits (Akhtar, Anjum, \& Anjum, 2011; Oghbaei \& Prakash, 2012; Serdula, 2010a, 2010b).

Wheat and maize flours can be fortified with several micronutrients and reduce vitamin, mineral and other micronutrients deficiencies when identified as health public problem. It is estimated that the amount of industrial flour fortified is $97 \%$ in the Americas, $21 \%$ in Southeast Asia, 6\% in Europe, 4\% in the Western Pacific, 31\% in Africa, and $44 \%$ in the Mediterranean area in 2007-2008 (WHO, 2009). Efforts made by some countries to adopt mandatory fortification of flours with some micronutrients are useful in combating these deficiencies. These initiatives are an excellent example for other countries, considering their own programs, however, when it comes to food fortification, appropriate legislation is needed to ensure impact and safety, and the intended benefits to health (Luthringer, Rowe, Vossenaar, \& Garretta, 2015; Serdula, 2010a). Therefore, it is necessary to explore how nutrient fortification contributes to the context of the current nutrient intakes. The aim of this review is to evaluate the impact of flour fortification for nutritional and health improvement, detailing the prevalence of micronutrient deficiencies, health consequences, and global trends and experiences regarding flour fortifications.

\section{Food fortification}

Food fortification has a long history of use in some countries and has successfully controlled micronutrient deficiencies (WHO \& FAO, 2006). World Health Organization (WHO) and the Food and Agriculture Organization of the United Nations (FAO), defines fortification as the practice of deliberately increasing the amount of a vital micronutrient, i.e. vitamins, minerals, amino acids among others, in a food regardless of whether the nutrients are initially in the food before processing or not, with the intention of improving the nutritional quality of the food and providing a public health benefit with little health risk (Whiting, Kohrt, Warren, Kraenzlin, \& Bonjour, 2016; WHO \& FAO, 2006). This strategy can lead to relatively rapid improvements in the number of people with food deficiencies within a population, since the benefits are potentially large and consists of very cost-effective public health interventions (Dwyer et al., 2015; WHO, 2009).

The advantages of fortification to public health has been demonstrated over time by the scientific community, helping in the micronutrients deficiency correction and prevention or reduction of these deficiencies in a population, having the capacity to improve nutritional status and dietary intake and consequently improving eating habits and lifestyles (FAO et al., 2018; WHO \& FAO, 2006).

To have consolidated results in food fortification, the micronutrient used must have a good availability of absorption by the organism, ideal organoleptic characteristics (not changing the colour and the flavour of the fortified food), be easily accessible, should belong to the usual diet of the population and have a good acceptance.

The most common fortified foods are cereals and cereal products, milk and dairy products, fats and oils, tea and other beverages and various condiments such as salt, soy sauce, sugar and infant formulas (Pacho, Spohrer, Mei, \& Serdula, 2015; Whiting et al., 2016; WHO \& FAO, 2006). In the early 1920s salt iodization was adopted in Switzerland and the United States of America and today it is used in most

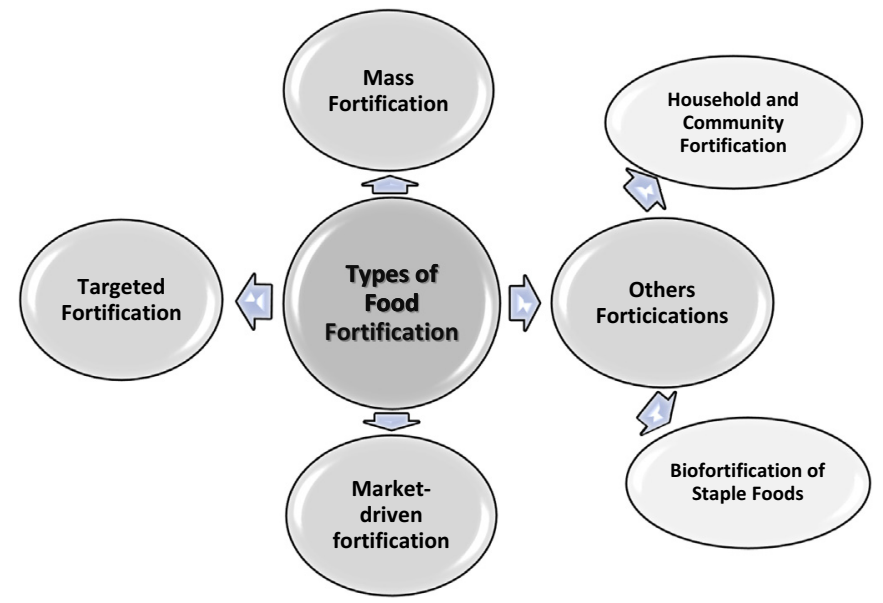

Fig. 1. Different types of food fortification.

countries. From the 1940s, fortification of cereal products with thiamine, riboflavin, and niacin became a common practice. In Denmark, margarine was fortified with vitamin A and in the United States milk with vitamin $\mathrm{D}$. Also, one procedure that significantly reduced the risk of iron deficiency anaemia in young children, was the fortification of foods with iron (Vlaic et al., 2019; WHO \& FAO, 2006). Nowadays, fortification of foods with different types of micronutrients has spread throughout the world, for example, folic acid fortification has spread in the Americas, a tactic adopted by the United States and Canada and approximately 20 Latin American countries (FAO et al., 2018; Vlaic et al., 2019).

\subsection{Types of fortification}

According WHO and FAO, food fortification includes different forms (Fig. 1): i) mass fortification (fortify foods that are quite consumed by the general population), ii) targeted fortification (fortify food targeted to specific population groups, e.g. small children), and iii) marketdriven fortification (ensure that food is available in the market). There are other types of fortification such as household fortification (addition of micronutrients to homemade foods, namely a fusion of supplements and fortification) and biofortification of staple foods (breeding and genetic modification of plants to improve the content and the absorption of nutrients) (WHO \& FAO, 2006).

Generalizing, mass fortification is often mandatory, targeted fortification is mandatory or voluntary and depends on the importance for public health, and market-driven fortification is always voluntary, but controlled by regulatory limits (Liyanage \& Hettiarachchi, 2011; Marques, Marques, Xavier, \& Gregório, 2012; WHO \& FAO, 2006).

According to Liyanage and Hettiarachchi (2011), commercial and industrial fortification includes available products, such as flour, rice, cooking oils, sauces, butter, etc. and the procedure takes place throughout the manufacturing process. On the contrary, the biofortification encompasses the creation of micronutrient cultures using traditional breeding and/or biotechnology techniques (for example, transgenic "Golden Rice" containing higher amounts of iron and significant levels of beta-carotene (Lonnerdal, 2003). There is also microbial biofortification, which includes the use of probiotic bacteria, which ferment to produce $\beta$-carotene in foods or directly in the intestine. For example, the use of animal feed enriched with these bacteria (more specific lactic acid bacteria), so that meat, milk and bioproducts are enriched with vitamin A (Liyanage \& Hettiarachchi, 2011; Sasson, 2005). Moreover, there is home fortification, where micronutrients obtained from packages or tablets can be incorporated when cooking and or consumed in a homemade meal to fill micronutrient deficiencies in the populations (Liyanage \& Hettiarachchi, 2011; Marques et al., 


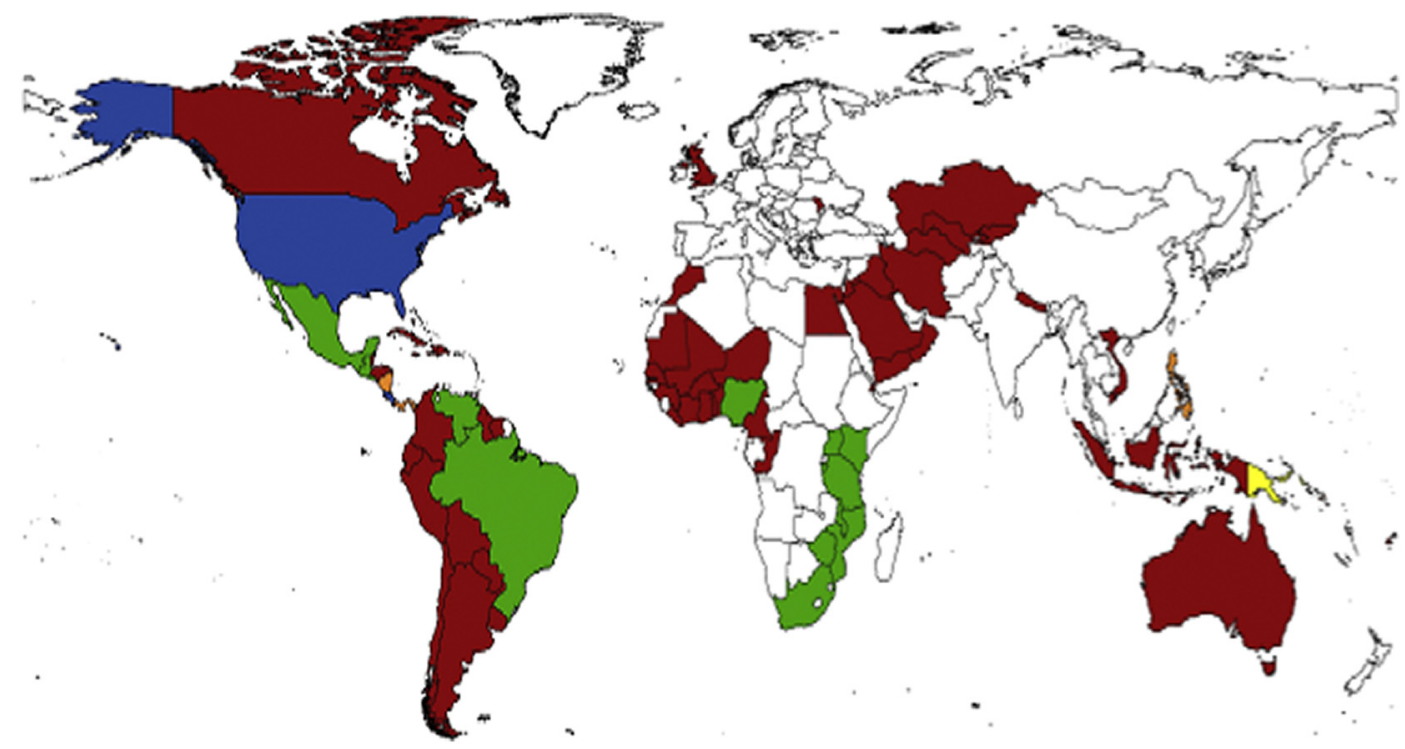

Fig. 2. Mandatory fortification of different types of flour around the world:

65 countries - wheat flour,

14 countries - wheat flour and maize flour, countries - wheat flour and rice (Nicaragua, Panama, Philippines, Solomon Islands), 2 countries - wheat flour, maize flour and rice (Costa Rica and the United States), 1 country - rice (Papua New Guinea) (FFI, 2019a, 2019b, 2019c, 2019d, 2019e).

2012; WHO \& FAO, 2006).

\subsection{Issues and challenges of nutrient deficiencies}

The greatest modifiable threat to global health and survival is represented by malnutrition, especially among children in the world's poorest countries (Prentice et al., 2008). Given the increasing demands of pregnant and lactating women and young children, this group is among the most vulnerable to micronutrient deficiencies (Black et al., 2013).

WHO reports that worldwide approximately 19.1 million pregnant women are deficient in vitamin A and it is estimated that $82 \%$ of these women have zinc intake inappropriate to meet the normal needs of pregnancy; 100 million women of reproductive age have iodine deficiency; 190 million pre-school children are also deficient in vitamin A; iron deficiency is globally found worldwide and approximately 1.62 billion people are anaemic (mostly among pre-school children and pregnant women). Deficiencies of vitamin B6 and B12 have also been observed in many countries (McLean, de Benoist, \& Allen, 2008; WHO, 2000, 2009).

Wide spreading of infectious diseases and mortality from pneumonia, malaria, diarrhoea and measles are linked to micronutrient deficiency. Proper nutrition influences health status and helps prevent many diseases, being responsible for providing nutrients (including vitamins, minerals and others nutrients), and contributing to the proper functioning of the body (Jakubowska \& Staniewska, 2015). The implications of these shortcomings are not only limited to health standards, but also have effects on the economy, through secondary physical and mental disabilities and modified work productivity (Das, Salam, Kumar, \& Bhutta, 2013). Currently the approach to nutritional issues has undergone considerable changes.

Nowadays solutions are already known (such as fortified foods), but require some challenges like political dedication, economic advancement, and scientific research, in order to range a plausible solution. In this sense, several agencies worldwide are focusing their attention on the fight against micronutrient deficiencies, since they are a short-term resolution (FAO, 2017; Prentice et al., 2008). Some challenges, such as choosing appropriate fortification vehicles, having a good policy, targeting populations, avoiding excessive consumption in non-target groups, and monitoring nutritional status, are among relevant factors in improving health and will have the possibility to save billions of lives
(Dwyer et al., 2015; Osendarp et al., 2018; Prentice et al., 2008; WHO \& FAO, 2006).

\section{Fortification of flour around the world}

Worldwide, millions of tons of flours are used for human consumption each year, they are consumed as noodles, breads, pasta and other flour products (Pacho et al., 2015; Serdula, 2010b). In 2016, according to the Food Fortification Initiative, out of the 250 metric tons of industrially milled wheat flour, 26 metric tons of industrially milled maize flour, and 171 metric tons of industrially milled rice, 34\%, 57\%, and $1 \%$, respectively for each one of the flours was fortified. Between 2016 and 2017, 87 countries have decided to fortify at least one of these cereals (FFI, 2016, 2018; Marks et al., 2018).

The first cereal product to be largely fortified was wheat flour, and the first recommendations about cereals fortification from the World Health Organization (WHO) referred to maize and wheat flour. At the beginning of 2015, 83 countries demanded the fortification of wheat flour, of which 14, required simultaneously the fortification of maize flour. Most of these countries require fortification of wheat flour and maize with at least iron and folic acid, excluding Australia that does not require fortification of flour with iron, and Congo, Nigeria, Philippines, United Kingdom, and Venezuela do not require flour fortification with folic acid (Pacho et al., 2015; WHO, 2009).

Today, just 86 countries worldwide have legislation requiring the fortification of at least one grain of industrially milled cereal, depending on the country the flour is fortified with vitamins, minerals, amino acids and other micronutrients. Within these, 85 countries fortify wheat flour alone or in combination with other grains, taking away the country Papua New Guinea which is mandated only for rice flour fortification (Fig. 2) (FFI, 2019c).

Each country adopts its fortification standard depending on the geographic region, income status, food vehicle(s) and nutrient(s). The total number of nutrients fortified in flours are determined according to the fortification pattern (Table 1) (GFDx, 2019).

Nutrition International directs and supports flour fortification efforts in developing countries through various programs and partners such as: Global Alliance for Improved Nutrition (GAIN), UNICEF, World Food Program (WFP), Food Fortification Initiative (FFI), Unite State Centres for Disease Control and other organizations, working within different countries (South Africa, Yemen, Iran, India, Pakistan, Nepal, 
Table 1

Nutrients in food fortification standards of some country (GFDx, 2019; WHO, 2013).

\begin{tabular}{|c|c|c|}
\hline Country & Food vehicle & Nutrients \\
\hline Afghanistan & Wheat flour & Vitamin B12, Folate (B9), Iron, Zinc \\
\hline Bolivia & Wheat flour & Niacin (B3), Riboflavin (B2), Thiamine (B1) \\
\hline \multirow[t]{3}{*}{ Costa Rica } & Wheat flour & Folate (B9), Iron, Niacin (B3), Riboflavin (B2), Thiamine (B1) \\
\hline & Rice & Folate (B9), Vitamin B12, Niacin (B3), Selenium, Thiamine (B1), Vitamin E, Zinc \\
\hline & Maize flour & Folate (B9), Iron, Niacin (B3), Riboflavin (B2), Thiamine (B1) \\
\hline \multirow[t]{2}{*}{ Tanzania } & Wheat flour & Vitamin B6, Vitamin B12, Folate (B9), Iron, Niacin (B3), Riboflavin (B2), Thiamine (B1), Vitamin A, Zinc \\
\hline & Maize flour & Vitamin B12, Folate (B9), Iron, Zinc \\
\hline Colombia & Wheat flour & Calcium, Folate (B9), Niacin (B3), Riboflavin (B2), Thiamine (B1) \\
\hline \multirow[t]{2}{*}{ Philippines } & Wheat flour & Iron, Vitamin A \\
\hline & Rice & Iron \\
\hline \multirow[t]{2}{*}{ Nigeria } & Wheat flour & Zinc, Vitamin A, B6, B12, Folate (B9), Iron, Niacin (B3), Riboflavin (B2), Thiamine (B1) \\
\hline & Maize flour & Zinc, Vitamin A, Thiamine (B1), Riboflavin (B2), Niacin (B3), Iron, Folate (B9), Vitamin B12 And B6 \\
\hline Nepal & Wheat flour & Folate (B9), Iron, Vitamin A \\
\hline \multirow[t]{2}{*}{ United States of America } & Maize flour & Calcium, Folate (B9), Iron, Niacin (B3), Riboflavin (B2), Thiamine (B1), Vitamin D \\
\hline & Rice & Thiamine (B1), Vitamin D \\
\hline
\end{tabular}

Bolivia, Central and South America and the Middle East, Indonesia, Nigeria, among others countries). They support and expand fortification programs of flours with different micronutrients to combat the deficiency of these nutrients and improve health disorders (Nutrition International, 2019).

\subsection{Types of fortified flours}

Since the early days, cereals and cereal products have been the main components of the human diet throughout the world. Major cereal crops include wheat, rice, maize and barley. Maize (or corn) is the most produced, but it is less important than wheat and rice, which are the most important cereals for human nutrition (Preedy, Watson, \& Patel, 2011).

Cereals are common staple foods since they are versatile, tasty, always available on the market, accessible and culturally acceptable, are consumed every day by all age groups, being a great fortification vehicle.

Cereals are commonly consumed after being processed by milling industries. When the flours are fortified at the industrial level (flour production), the different produced food products in the food preparation industries (e.g. bakeries) are easier to prepared. This makes the cereal industrial unit much more powerful in this type of fortification, than the a bakery, or even supplements (Johnson, Mannar, \& Ranum, 2004; Pacho et al., 2015).

Wheat flour was the first cereal grain product to be extensively fortified and the recommendations of the World Health Organization (WHO) is that fortification of wheat, maize and rice flour are an opportunity to improve health (WHO, 2009). Table 2 presents some types of flours or derived products that have already been fortified and it is found that the work on fortifications has been made mostly in wheat flour.

In the market there are many flours that can be fortified or used to fortify other flours, the following topics highlight the main produced and/or consumed cereals flours worldwide.

\subsubsection{Wheat flour}

The third largest cereal production in the world is wheat, after maize and rice, and is the second most consumed by the populations after rice. Wheat flour is considered one of the most appropriate vehicles for multi-micronutrient fortification because of its worldwide consumption and given the high consumption of bread and pasta worldwide (Awika, 2011; Peña-Rosas, Field, Burford, \& De-Regil, 2014).

The industrial processed fortification of wheat flour, when properly implemented, is an effective, simple and inexpensive strategy to provide vitamins and minerals to the world population, thereby improving the nutritional quality of food supply and providing a public health benefit (Cardoso et al., 2019; FFI, 2019b; Nuria Mateo Ansón, 2010; Peña-Rosas et al., 2014).

Globally the effort to begin fortifying wheat flour was launched during the 1940s as a way to improve the health of populations (Bishai \& Nalubola, 2002). Wheat flour has been fortified with different micronutrients such as iron, folic acid, B-complex vitamins, vitamin A, D and $\mathrm{C}$, zinc, calcium among others, in different parts of the world (Akhtar et al., 2011; FFI, 2019b, 2019c; Johnson et al., 2004; Jungjohann et al., 2015; Marks et al., 2018; Pacho et al., 2015; PeñaRosas et al., 2014; Rebellato et al., 2017; Serdula, 2010b; WHO, 2009). For example, pasta made with white wheat flour, enriched with Oreochromis niloticus L. (high levels of essential amino acids and polyunsaturated fatty acids) flour, improves the nutritional composition of the pasta without compromising its sensorial quality (Monteiro et al., 2019).

\subsubsection{Rye flour}

Rye is essentially a European cereal and globally the largest production is also centred in Europe. In the baking industry, it is the second most used cereal worldwide, after wheat. In the Middle East, rye is developed as a secondary crop, it has a great wintering capacity and high tolerance to drought, cold, and develops well on low fertility soils. With these characteristics, it becomes a low-risk and economical crop (Cardoso et al., 2019; Carena, 2009; Kaminski, da Silva, do Nascimento Júnior, \& Ferrão, 2011; Redant, Buggenhout, Brijs, \& Delcour, 2017).

The interest in rye has been increasing because of its nutritional profile, due to its high levels in dietary fibre. Beside its excellent nutritional quality, it also has many health benefits, decreasing the absorption of triglycerides and blood cholesterol levels; reduction in blood glucose; prevention of constipation, and prebiotic effects, among others. These characteristics, allow the classification of rye products as functional foods, proving a relationship between diet and health (Carena, 2009; EFSA Panel on Dietetic Products Nutrition and Allergies (NDA), 2011; Grossmann \& Koehler, 2016; Kaminski et al., 2011; Moniz et al., 2018; Preedy et al., 2011; Redant et al., 2017). There are some studies that have presented the fortification of rye flour with cellulose fibre (Fuckerer, Hensel, \& Schmitt, 2015, 2016) and with folic acid (Gujska \& Majewska, 2005) to increase its health benefits.

\subsubsection{Rice flours}

Rice is the staple food for more than half the world's population and is the main cereal in many developing countries. In most Asian countries, rice provides between $50 \%$ and $80 \%$ of the caloric intake. In South and Southeast Asia, most women and children are anaemic and the nutritional value of rice has a significant impact in their health (FFI, 2019e; Preedy et al., 2011; Sasson, 2005; WHO, 2018a). 
Table 2

Flour fortification with micronutrients and their health benefits.

\begin{tabular}{|c|c|c|c|}
\hline Flours & Micronutrients $^{\mathrm{a}}$ & Health benefits ${ }^{\mathrm{b}}$ & References \\
\hline Wheat & $\begin{array}{l}\text { Proteins } \\
\text { Fibre } \\
\text { Fatty acids }\end{array}$ & $\begin{array}{l}\text { Increases the content or bioavailability of a specific } \\
\text { micronutrients } \\
\text { Prevention/reduction/improvement of the incidence } \\
\text { of anaemia or specific mineral deficiency } \\
\text { Functional food with therapeutic protective effects } \\
\text { against diabetes and cardiovascular diseases } \\
\text { Effect on the prevention of colon cancer } \\
\text { Antioxidants activity } \\
\text { Prevention of civilization diseases (e.g.: hypertension, } \\
\text { obesity) }\end{array}$ & $\begin{array}{l}\text { Chiplonkar et al. (1999), Gujska and Majewska (2005), Towo, Mgoba, Ndossi, and Kimboka } \\
\text { (2006), Butt, Arshad, Alam, and Nadeem (2007), Gigante and Victora (2007), Naves et al. } \\
\text { (2007), Akhtar, Anjum, Rehman, Sheikh, and Farzana (2008), Pachón, Stoltzfus, and Glahn } \\
\text { (2008), Sadighi et al. (2008), Anton, Lukow, Fulcher, and Arntfield (2009), Škrbić, Milovac, } \\
\text { Dodig, and Filipčev (2009), Berry et al. (2010), Kaminski et al. (2011), Barbosa, Taddei, } \\
\text { Palma, Ancona-Lopez, and Braga (2012), Buzzo et al. (2012), Fares and Menga (2012), } \\
\text { Erukainure, Ebuehi, Adeboyejo, Aliyu, and Elemo (2013), Danza et al. (2014), Peña-Rosas } \\
\text { et al. (2014), Gawlik-Dziki et al. (2015), Pacho et al. (2015), Prodhan et al. (2015), } \\
\text { Muhammad et al. (2016), Sui, Zhang, and Zhou (2016), Bolarinwa, Aruna, and Raji (2017), } \\
\text { Kurek, Wyrwisz, Karp, and Wierzbicka (2017), Rebellato et al. (2017), Reshmi, Sudha, and } \\
\text { Shashirekha (2017), Aranibar et al. (2018), Armellini et al. (2018), Benjakul and } \\
\text { Karnjanapratum (2018), Emaleku, Omueti, and Emaleku (2018), Garrod et al. (2019), and } \\
\text { Hemery et al. (2018) } \\
\text { Jakubczyk, Świeca, Gawlik-Dziki, and Dziki (2018), Moniz et al. (2018), Rebellato et al. } \\
\text { (2018), Sheikholeslami, Karimi, Komeili, and Mahfouzi (2018), and Bryszewska et al. } \\
\text { (2019) }\end{array}$ \\
\hline Rye & $\begin{array}{l}\text { Fibre } \\
\text { Vitamins }\end{array}$ & Increases the content of a specific micronutrients & Gujska and Majewska (2005), Fuckerer et al. (2015), and Fuckerer et al. (2016) \\
\hline Maize & $\begin{array}{l}\text { Minerals } \\
\text { Vitamins }\end{array}$ & $\begin{array}{l}\text { Increases the content or bioavailability of a specific } \\
\text { micronutrients } \\
\text { Prevention/reduction/improvement of the incidence } \\
\text { of anaemia or specific mineral deficiency } \\
\text { Antioxidants activity }\end{array}$ & $\begin{array}{l}\text { Chiplonkar et al. (1999), Hansen, Bæch, Thomsen, Tetens, and Sandström (2005), Towo } \\
\text { et al. (2006), Andang'o et al. (2007), Gigante and Victora (2007), Naves et al. (2007), Bilgi } \\
\text { Boyaci et al. (2012), Buzzo et al. (2012), Pacho et al. (2015), Giménez, Drago, Bassett, Lobo, } \\
\text { and Sammán (2016), and Kumar, Xavier, Lekshmi, Balange, and Gudipati (2018) }\end{array}$ \\
\hline Rice & $\begin{array}{l}\text { Minerals } \\
\text { Vitamins } \\
\text { Fibre }\end{array}$ & $\begin{array}{l}\text { Increases the content or bioavailability of a specific } \\
\text { micronutrients } \\
\text { Antioxidants activity }\end{array}$ & $\begin{array}{l}\text { Hettiarachchi et al. (2004), Sharif, Rizvi, and Paraman (2014), Igoumenidis, Lekka, and } \\
\text { Karathanos (2016), Kumar et al. (2018), and Mounjouenpou et al. (2018) }\end{array}$ \\
\hline Millet & $\begin{array}{l}\text { Minerals } \\
\text { Vitamins }\end{array}$ & $\begin{array}{l}\text { Increases the content or bioavailability of a specific } \\
\text { micronutrients }\end{array}$ & $\begin{array}{l}\text { Chiplonkar et al. (1999), Tripathi and Platel (2010), Tripathi, Chetana, and Platel (2010), } \\
\text { and Tripathi and Platel (2011) } \\
\text { Tripathi, Platel, and Srinivasan (2012), Tripathi and Platel (2013), and Oluyimika, Kruger, } \\
\text { White, and Taylor (2019) }\end{array}$ \\
\hline Sorghum & $\begin{array}{l}\text { Minerals } \\
\text { Proteins } \\
\text { Fatty acid } \\
\text { Amino acids }\end{array}$ & $\begin{array}{l}\text { Increases the content or bioavailability of a specific } \\
\text { micronutrients } \\
\text { Increases the content of protein and fatty acid } \\
\text { Antioxidant activity }\end{array}$ & $\begin{array}{l}\text { Chiplonkar et al. (1999), Tripathi and Platel (2010), Tripathi and Platel (2011), Tripathi } \\
\text { et al. (2012), Tripathi and Platel (2013), and Abdualrahman et al. (2019) }\end{array}$ \\
\hline
\end{tabular}

\footnotetext{
${ }^{\text {a }}$ In this section, the micronutrients have been used directly or they are derived from other foods that are used to fortify the flours.

b Some of the health benefits that can be found in referenced works.
}

Such as wheat and maize flour fortification, rice fortification with vitamins, minerals and other micronutrients is a public health opportunity, in order to prevent deficiencies in these compounds and severe diseases (de Pee, 2014; FFI, 2019e; Forsman, Milani, Schondebare, Matthias, \& Guyondet, 2014).

According to GFDx (2019) some countries like Costa Rica, Nicaragua, Panama, Papua New Guinea, Philippines, United States of America, Bangladesh, India and Venezuela fortify rice with zinc, vitamin A, vitamin B1, B2, B3, B6, B9, and B12, iron, calcium, and vitamin D.

However, rice is very difficult to fortify because most of the grains are not processed. Therefore, the alternative is to fortify rice flour instead of rice grain, which can be fortified with the same methods used for the other flours. In Sri Lanka, rice flour is processed, and its cost is approximately equal to wheat flour, leading to a growing interest by the population. Mounjouenpou et al. (2018) fortified rice flour biscuits with $20 \%$ baobab (Adansonia digitata L.) pulp flour, which has been shown to be very rich in minerals, such as potassium, magnesium, iron and calcium, as also vitamin $\mathrm{C}$ and total fibre. According to the authors the biscuits with baobab appears to be a very low cost alternative and an accessible way to combat micronutrient deficiencies in Africa. Fortification of rice flour has been proposed in countries such as the Philippines and Guyana, which have a very significant consumption of this product (Hettiarachchi, Hilmers, Liyanage, \& Abrams, 2004; Johnson et al., 2004; Marks et al., 2018).

\subsubsection{Maize flours}

Maize is grown all over the world and millions of tonnes are produced, actually, different types of maize, varying colours, are cultivated globally. The United States, China, India, France, Brazil, Argentina, and Indonesia are the main maize producing countries. It is also the main food preferred by billions of consumers in sub-Saharan Africa and Latin America. Tons of maize flours are milled annually, and its consumption is performed in many forms. After wheat and rice, maize is the third most frequently consumed cereal in the world (Sasson, 2005; WHO, 2009).

Around $65 \%$ of industrially processed maize in the world is fortified (FFI, 2018, 2019d) and this fortification has been practiced for several years in many countries, where this ingredient is used for the preparation of many common dishes. Between the African and American continent about 16 countries have mandatory legislation to fortify maize flour (Enzama, Afidra, Johnson, \& Verster, 2017; FFI, 2019d). Maize flour can be fortified with several micronutrients, such as iron, folic acid, vitamin A and B, zinc, among others; some of them are used to replace nutritional contents and others are used to prevent deficiencies of certain micronutrients relevant to health (GFDx, 2019; WHO, 2016). For example tortilla made from maize flour incorporated with Moringa oleifera Lam. flour showed a significantly increased in the protein and lipid content of this food product and an increase in total polyphenolic content as well as its antioxidant activity (PáramoCalderón et al., 2019).

\subsection{Flour fortification as a supplement}

Supplementation is a set of substances (vitamins, minerals or other nutrients) that serve to complement your diet when the natural intake of these components is insufficient; this term is used to describe large doses of micronutrients, usually in the form of capsules, tablets or 
syrups. It has the advantage of offering the ideal amount of specific micronutrients in an absorbable form and is often the fastest way to combat nutrient deficiency (Bailey, Fulgoni, Keast, Lentino, \& Dwyer, 2012; Dwyer et al., 2015; WHO \& FAO, 2006).

Worldwide, supplementation programs have been widely used to provide iron, folic acid, vitamin A among other nutrients to pregnant women, infants, children under 5 years, among other groups of individuals (Datta \& Vitolins, 2016). However, as for the more watersoluble vitamins and minerals, the populations or target populations need to consume the supplements more often for the control and combat for this type of micronutrient deficiencies. Flour fortification with micronutrients (Table 2) has been widely implemented worldwide, due to the extensive consumption of these foods in different forms and for being a cost-effective and sustainable strategy (Datta \& Vitolins, 2016; Marks et al., 2018; Pacho et al., 2015).

As it has been described earlier, there are different types of micronutrients that can be used to supplement food, the following topics highlight the major micronutrients used to fortify flours worldwide.

\subsubsection{Vitamins}

Vitamins are essential nutrients for growth and maintenance of life, since our organism does not have the capacity to synthesize them, we must guarantee their ingestion through food or supplements. These compounds are present in very small quantities and are linked to various processes related to the transfer and storage of energy, protection and strengthening of the body's defences, protection against various diseases, bone and tissue formation, formation and maintenance of cellular structure and functions, visual system, activity of other nutrients, etc. (Das et al., 2013; Johnson et al., 2004; Verma, 2015).

It has been reported the use of fortified flours with different vitamins to reduce nutritional deficiencies and to prevent and control various diseases. For example, rice has been fortified with vitamin A, to improve the iron status and vitamin A nutrition of populations, while maize flour has been fortified with B vitamins, contributing in the elimination of beriberi and pellagra in many countries, also vitamin B12 added as a fortifier for flour retains high bioavailability when baked in bread, which when consumed contributes in the diminution in this vitamin deficiency (Akhtar et al., 2011; Das et al., 2013; Garrod et al., 2019; Johnson et al., 2004; Peña-Rosas et al., 2014; Serdula, 2010a; WHO, 2018a), vitamin D has been used to fortified chapattis consumed by residents of private sunbeds in Romania, showing higher serum vitamin D levels and significantly increased bone density (Allen, Dangour, Chalabi, \& Tedstone, 2015; Ritu \& Gupta, 2015; WHO, 2016).

\subsubsection{Minerals}

Minerals (sodium, potassium, calcium, iron etc.) are nutrients important to the body and are responsible for the proper functioning of metabolism. They favour the balance and maintenance of basic bodily functions such as conduction of nerve impulses, cellular activity and maintenance, and structural functions in the body, nail, tooth, and bone formation (Akhtar et al., 2011; Peña-Rosas et al., 2014; WHO, 2009; WHO \& FAO, 2006). The different essential minerals are classified according to their concentration in the body and the requirement in the diet. The differences in the required mineral quantity has a great influence on the cost and on other aspects of mineral fortification of the flours. The main minerals for our organism are calcium, phosphorus, sodium, potassium, chloride and magnesium, while those that are needed in smaller quantities are iron and zinc, and the trace elements needed are iodine, copper and selenium (BNF, 2019; Peña-Rosas et al., 2014; Serdula, 2010a; WHO, 2016).

There are several studies demonstrating the use of minerals to strengthen different types of flours in order to reduce their deficiencies and prevent/control some diseases. Iron deficiency leads to anaemia and is one of the most prevalent public health problems in the world, and for example, in Iran, the fortification of flour with iron is considered a strategy to combat this deficiency (Blanco-rojo \& Vaquero,
2019; Sadighi et al., 2008; WHO \& FAO, 2006). Currently, every wheat flour sold in many countries are enriched with iron in order to reduce iron deficiency and anaemia caused by low intakes of bioavailable iron (Rebellato, Klein, Wagner, \& Lima Pallone, 2018). Zinc is being added to maize flour in South Africa and Mexico and in wheat flour in Mexico, South Africa, Central Asia and Indonesia to address the problem of their deficiency (delayed growth and increased risk of disease), especially in children (Johnson et al., 2004; WHO, 2017; WHO \& FAO, 2006). The fortification of calcium in whole wheat flour in Asia has been performed in order to increase the amount of calcium in the body and to combat some diseases, such as osteoporosis (Muhammad et al., 2016; WHO, 2017).

\subsubsection{Other nutrients}

There are many other micronutrients with health benefits that can be used to fortify flours. Fibre deficiency has a negative impact on quality of life and can lead to serious health problems. Food fibres can be classified as soluble and insoluble fibres. Both types of fibre have several health benefits, including maintaining intestinal integrity and overall health, lowering blood cholesterol levels, controlling blood sugar levels, and providing non-caloric volume that may help in the loss of weight ratio by replacing caloric components. In this sense, fortification of flours with fibre can bring many health benefits (Anderson et al., 2009; Salmean, Zello, \& Dahl, 2013).

Proteins belong to a category of compounds that are essential to life through its specific action. They are important for cell walls, muscles, blood, hair, internal organs, such as the heart and brain, among others, also for hormones, enzymes and antibodies, and replacement of waste cells. Essential amino acids can only be acquired through food, because the body cannot produce them by itself. One advantage may be the fortification of products with plant proteins, for example, the fortification of wheat flour with chickpeas, amaranth, quinoa, lentils and mushroom powder, etc. (Preedy et al., 2011; Prodhan, Linkon, Al-Amin, \& Alam, 2015).

Essential fatty acids are also an important nutrient, especially for the cardiovascular system. Essential fatty acid deficiency is uncommon, but include scaly dermatitis, alopecia, thrombocytopenia and, in children, intellectual disability. Diets in the West are deficient in omega-3 fatty acids. Although there is not much mentioned about fortified flours with essential fatty acids, there are products derived from flour that have been incorporated with these compounds (e.g.: breads fortified with oils containing omega-3). Nevertheless, there are other products that have been fortified with essential fatty acids that include meat, oil, butter, jelly, different types of sauces, etc. (Preedy et al., 2011; Vlaic et al., 2019).

\subsection{Flour fortification with bioactive compounds}

The usefulness of food fortification is mostly given to bioactive compounds such as vitamins, minerals, phenolic compounds, essential amino acids, dietary fibre, among other group of compounds. By fortifying day-to-day foods we can guarantee the necessary micronutrients ingestion in order to stay healthy (Del Pino-García, Rico, \& MartínDiana, 2018).

There are many natural sources with bioactive compounds that can be used to fortify flours, a good example could be mushrooms, which can provide relevant amounts of B vitamins, ergosterol (precursor of vitamin D2) and minerals such as selenium, potassium, copper and zinc. Mushrooms are nutritious foods and an excellent source of bioactive compounds, and they have already been used to fortify wheat flour in order to increase the availability of different micronutrients (Cardwell, Bornman, James, \& Black, 2018; Prodhan et al., 2015). Moreover, wheat and maize flours have been fortified with egg shell powder as a source of calcium, with finger millet (excellent source of bioactive compounds), due to its high concentration in fibres, minerals, protein, and calcium (Naves, Fernandes, Prado, \& Telxeira, 2007; Oghbaei \& 
Table 3

Some natural sources used as flour fortifiers ${ }^{\mathrm{a}}$.

\begin{tabular}{|c|c|c|c|}
\hline \multicolumn{2}{|c|}{ Natural sources (origin) } & $\begin{array}{l}\begin{array}{l}\text { Class of bioactive } \\
\text { compounds }\end{array} \\
\text { Carotenoids }\end{array}$ & \multirow{2}{*}{$\begin{array}{l}\text { References } \\
\text { Archana and Neetu (2016), Cardwell et al. (2018), Chaudhari, Wandhekar, Shaikh, and Devkatte } \\
\text { (2018), Chauhan, Kumar, Kumar, and Kumar (2018), Condé, Oliveira, and Oliveira (2017), Ishara, } \\
\text { Sila, Kenji, and Buzera (2018), Mahamud, Shirshir, and Hasan (2012), Prodhan et al. (2015), } \\
\text { Sonkar and Singh (2015), and Sulieman et al. (2019) }\end{array}$} \\
\hline Mushrooms & $\begin{array}{l}\text { Agaricus bisporus } \\
\text { Pleurotus ostreatus } \\
\text { Boletus edulis } \\
\text { Cantharellus tubaeformis } \\
\text { Pleurotus sajor caju }\end{array}$ & $\begin{array}{l}\text { Phytosterols } \\
\text { Tocopherols } \\
\text { Flavonoids } \\
\text { Phenolic acid }\end{array}$ & \\
\hline Plants & $\begin{array}{l}\text { Aloe vera L. } \\
\text { Artocarpus integer (Thunb.) Merr. } \\
\text { Avena sativa L. } \\
\text { Chenopodium quinoa W. } \\
\text { Hordeum vulgare L. } \\
\text { Ipomoea batatas Lam. } \\
\text { Moringa oleifera Lam. } \\
\text { Pennisetrum glaucum (L.) R. Br. } \\
\text { Abelmoschus esculentus (L.) } \\
\text { Moench. (Flour) } \\
\text { Glycine max (L.) Merr. (Proteins) } \\
\text { Hordeum vulgare L. (Brewer's } \\
\text { Spent Grain) } \\
\text { Lupinus spp (Lupine Kernel Fibre) } \\
\text { Malus domestica Borkh. (Pomace) } \\
\text { Mangifera indica L. (Flours) } \\
\text { Musa spp (Flours) }\end{array}$ & Fatty acid & $\begin{array}{l}\text { Bolarinwa, Aruna, and Raji (2019), Izydorczyk and McMillan (2019), Montemurro, Pontonio, and } \\
\text { Rizzello (2019), Oyeyinka and Oyeyinka (2018), Preedy and Watson (2019), Preedy et al. (2011), } \\
\text { Sonkar and Singh (2015), and Urade (2019) }\end{array}$ \\
\hline
\end{tabular}

a The natural sources mentioned are already used to fortify flours or can be used for the same purpose.

b Classes of bioactive compounds that may be related to plants and/or mushrooms.

Prakash, 2012; Preedy et al., 2011).

Several non-wheat cereal flours are also used for substitution of a portion of wheat flour to improve the micronutrients content in breads, e.g.: rice, maize, amaranth, barley, oat, rye, emmer, buckwheat, spelt and sorghum. There are also other natural source that can be used to fortify flour and develop different types of products, as they contain a large number of bioactive compounds, for example chicken bones, used as a sources of calcium (Muhammad et al., 2016), these natural products, help to decrease micronutrient deficiency, and control/prevent several diseases (Berner et al., 2014). Table 3 shows some of the natural sources, namely plants and mushrooms, used as fortifiers and the class of bioactive compounds that can be targeted.

\subsection{Health benefits of fortified flour}

Flour fortification in the field of public health is a very attractive tactic and has the advantage of reaching massively a risk populations through existing food distribution systems, without widely changing existent patterns of consumption (Das et al., 2013; Preedy et al., 2011).

The benefits of fortification of flour or derivative flour products (Table 2), act in a positive way over the entire life cycle of the population, especially in children and pregnant women, preventing the birth of children with intellectual disabilities or malformations or deficiencies (Vlaic et al., 2019). It is one of the most efficient ways of combating malnutrition and controlling various diseases linked to vitamin or mineral deficiency (Santos \& Pereira, 2007; Vlaic et al., 2019). For example vitamin A fortified cereal flours can be effective to reduce this vitamin deficiency (Ranum, 2001); as previously described, flour fortification with iron is a strategy to combat iron deficiency in Iran (Sadighi et al., 2008); folic acid fortification programs in Chile have resulted in significant declines in the occurrence of pregnancies affected by neural tube defect (Berry, Bailey, Mulinare, Bower, \& Dary, 2010).

If consumed regularly, many are the health benefits that can be gained from fortified flour consumption, especially because it can help to maintain body reserves of nutrients in a more efficient way than supplements. Since fortified flours provide nutrients that are similar to those provided by an effective and balanced diet, fortified foods will contain "natural" amounts of nutrients and this does not happen with supplements by its own (Dwyer et al., 2015; Preedy et al., 2011; Whiting et al., 2016).

Flour fortification has the potential to improve the nutritional status of a large portion of the population, regardless of the social class, as they are a staple food widely distributed and consumed worldwide, and, this fortification does not require changes in existing food patterns of populations, being a very cost-effective method. It is also more efficient in reducing the risk of multiple deficiencies that can result from deficits in food supply or a poor diet. It is a major benefit primarily for women of childbearing age, during periods of pregnancy and lactation (increasing the rate of vitamins and minerals in breast milk and reducing the use of supplements) that need adequate amounts of micronutrients, as well as growing children, which need nutrients daily for growth and development (Berner et al., 2014; Das et al., 2013; Datta \& Vitolins, 2016; Dwyer et al., 2015; FFI, 2018; Johnson et al., 2004; Preedy et al., 2011). Moreover, it is also usually possible to add one or more micronutrient fortification (multi-nutrient fortification) without adding significantly to the total cost of the flour at the point of manufacture (Das, Salam, Kumar, Lassi, \& Bhutta, 2014; Dwyer et al., 2015; Whiting et al., 2016; WHO, 2009).

\section{Legislation and major issues regarding quality control}

The main objectives of food law are to protect consumer's health, facilitate trade, and protect consumer's fraud. In the case of fortified meals, the population should be protected from consuming toxic levels of micronutrients or nutritionally ineffective. Food fraud is committed to deceive consumers, it often arises from the need for competition between manufacturers, businesses, food establishments and large food retailers. Legislations are applied to require appropriate control in the fortification process to ensure that micronutrient levels are adequately within acceptable limits. The legislation also serves to prevent fortification with nutrients from unsafe or nutritionally unnecessary products, and the constant vigilance of the flours fortification industry, food fraud vulnerability assessments, brings benefits to the industry and ensures the safety and integrity of the supply chain of fortified flours 
(Esteki, Regueiro, \& Simal-Gándara, 2019; Marks et al., 2018; Spink, 2019).

The wide variety in each country's particularities and the public health goals worldwide have resulted in the development of many different approaches in the regulation of fortified foods. In most countries, fortification standards (in this case flour) are established by law or through cooperative arrangements. In some countries the fortification of food is achieved without any form of management guidance or quality control. With the increase distance between marketing food, whether fortified or not, from its place of production to the final consumer by Global Trade, has made it difficult to track the source of unintentional contamination and quality control concerns, and food safety (Esteki et al., 2019; Johnson et al., 2004). Quality control is performed to evaluate if the fortified product is following the established technical standards, using objective and measurable indicators. It typically consists of collecting samples of fortified food, depending on the production system, and determining its micronutrient content, since it is important to routinely collect and analyse the samples in order to verify and control whether the technical standards are being met. Quality control focuses on purely public health optics and, in this case, concentrates mainly on indicators and criteria that are relevant to the food fortification process (Johnson et al., 2004; Nestel \& Nalubola, 2002; Verma, 2015; WHO \& FAO, 2006).

The management tools available in order to establish an appropriate level of control over food fortification are food laws and related measures, as well as a broader food control system. This management has the function of protecting public health, being generally recommended that all forms of fortified foods be adequately regulated, to ensure that food fortification is safe and effective for certain population groups, mostly those with micronutrient deficiency risks (Marques et al., 2012; WHO \& FAO, 2006). Food fortification techniques follow the principles established by the Codex Alimentarius to ensure food security (FAO \& WHO, 2015). Any legislation on food fortification should also include the World Trade Organization (WTO) Agreement on the Application of Sanitary Measures (SPS) and the WTO Agreement on Technical Barriers to Trade (TBT), which have added new values to standards, guidelines, Codex codes and recommendations (FAO \& WTO, 2017; Orriss, 1998; WHO \& FAO, 2006).

In the legal context, fortification can be classified as mandatory or voluntary, which refers to the level of obligation imposed on producers of fortified foods to comply with the government's purposes evidenced by law (Datta \& Vitolins, 2016; WHO \& FAO, 2006). Mandatory fortification is where a manufacturer is legally obliged to add one or more micronutrients to a specific food or food product. Compulsory fortification can reach the general population or a specific group, depending on the consumption criterion of that food. For example, fortification of a staple food, such as flours, would increase consumption of a micronutrient in the general population, while fortification of complementary infant foods would only increase the intake of micronutrients from a target group. In controversy voluntary fortification occurs when a producer freely decides to fortify food, however, it varies depending on the micronutrient and the socio-political and legal environment present. Governments are advised to impose an appropriate degree of control over voluntary fortification, it should not only be consistent with general regulatory objectives but should also consider the General Principles of Codex for the addition of essential nutrients to food. Voluntary fortification is moved by a desire of the industry to promote trade and the consumer to increase consumption of micronutrients as a means to gain health benefits (FAO \& WTO, 2017; Hennessy, Walton, \& Flynn, 2013; Marks et al., 2018; WHO \& FAO, 2006).

In general, and according to the FFI, for wheat flour 82 countries have mandatory fortification and 10 countries have voluntary fortification, for maize flour 16 countries have mandatory fortification and 4 countries have voluntary fortification, while for rice 7 countries have mandatory fortification and 11 countries have voluntary fortification.
The list of countries that have mandatory or voluntary fortification can be consulted in FFI (2019a) and WHO (2018b).

\section{Concluding remarks and future perspectives}

Micronutrient deficiency is a serious problem that has adverse consequences and leads to economic and health tragedies for populations that are in risk around the world. Food fortification programs are extremely important to overcome and ensure the correct intake of micronutrients by these groups of population, so fortification of food is seen as an excellent methodology in the correction of nutritional deficiencies.

In general, flours are a potential vehicle for fortification, because of their high consumption worldwide. Nevertheless, the success of flour fortification is based on the correct evaluation of the prevalence of micronutrient deficiency, political opinions and their implementation, selection of fortifiers, levels of fortification, usual level of flour consumption and products derived from that staple food, fortification of other food vehicles, feasibility, cost and acceptability studies. Systems of monitoring and inspection of fortified products are also necessary.

Despite being fortification a mandatory priority for the international corporations to eliminate micronutrient deficiency, it remains a problematic issue in several countries. Thus, food fortification should be included into the national health and nutrition plans of each country, as a strategy to overcome micronutrients deficiency. These fortifications should include the incorporation of different micronutrients in the staple foods, in order to meet different purposes of millions of people around the world, being considered a low-cost, effective strategy with a low toxicity risk.

Moreover, the studies that have been performed until now, clearly show the high potential of fortifying flours as an alternative to combat micronutrient deficiencies, and consequently to control and/or eliminate various diseases, thus bringing nutritional benefits and improving health in general.

\section{Acknowledgment}

The authors are grateful to the Foundation for Science and Technology (FCT, Portugal) and FEDER under Programme PT2020 for financial support to CIMO (UID/AGR/00690/2019), R.V.C. Cardoso grant (SFRH/BD/137436/2018). L. Barros and A. Fernandes also thank the national funding by FCT - Foundation for Science and Technology, P.I., through the institutional scientific employment program-contract for their contracts. This work is funded by the European Structural and Investment Funds (FEEI) through the Regional Operational Program North 2020, within the scope of Project Mobilizador ValorNatural ${ }^{\oplus}$; and to FEEI through the Rural Development Program (PDR2020).

\section{Author contributions}

I.C.F.R. Ferreira and A.M.G.P. structured the manuscript; R.V.C.C wrote the manuscript with collaboration of A.F. and L. Barros; I.C.F.R. Ferreira, L.B. and A.M.G.P. reviewed the manuscript.

\section{Conflict of interest}

The authors declare that they do not have any conflict of interest.

\section{References}

Abdualrahman, M. A. Y., Ma, H., Yagoub, A. E. G. A., Zhou, C., Ali, A. O., \& Yang, W. (2019). Nutritional value, protein quality and antioxidant activity of Sudanese sorghum-based kissra bread fortified with bambara groundnut (Voandzeia subterranea) seed flour. Journal of the Saudi Society of Agricultural Sciences, 18, 32-40.

Akhtar, S., Anjum, F. M., \& Anjum, M. A. (2011). Micronutrient fortification of wheat flour: Recent development and strategies. Food Research International, 44, 652-659. Akhtar, S., Anjum, F. M., Rehman, S. U., Sheikh, M. A., \& Farzana, K. (2008). Effect of 
fortification on physico-chemical and microbiological stability of whole wheat flour. Food Chemistry, 110, 113-119.

Allen, R. E., Dangour, A. D., Chalabi, Z., \& Tedstone, A. (2015). Does fortification of staple foods improve vitamin D intakes and status of groups at risk of deficiency? A United Kingdom modeling study. Proceedings of the Nutrition Society, 74, 338-344.

Andang'o, P. E., Osendarp, S. J., Ayah, R., West, C. E., Mwaniki, D. L., De Wolf, C. A., Verhoef, H. (2007). Efficacy of iron-fortified whole maize flour on iron status of schoolchildren in Kenya: A randomised controlled trial. Lancet, 369, 1799-1806.

Anderson, J. W., Baird, P., Davis, R. H., Ferreri, S., Knudtson, M., Koraym, A., ... Williams, C. L. (2009). Health benefits of dietary fiber. Nutrition Reviews, 67, 188-205.

Anton, A. A., Lukow, O. M., Fulcher, R. G., \& Arntfield, S. D. (2009). Shelf stability and sensory properties of flour tortillas fortified with pinto bean (Phaseolus vulgaris L.) flour: Effects of hydrocolloid addition. LWT - Food Science and Technology, 42, 23-29.

Aranibar, C., Pigni, N. B., Martinez, M., Aguirre, A., Ribotta, P., Wunderlin, D., \& Borneo, R. (2018). Utilization of a partially-deoiled chia flour to improve the nutritional and antioxidant properties of wheat pasta. LWT - Food Science and Technology, 89, 381-387.

Archana, V., \& Neetu, S. (2016). Optimization of mushroom fortified noodles on their sensory attributes. International Journal of Food Science and Nutrition, 1, 44-45.

Armellini, R., Peinado, I., Pittia, P., Scampicchio, M., Heredia, A., \& Andres, A. (2018). Effect of saffron (Crocus sativus L.) enrichment on antioxidant and sensorial properties of wheat flour pasta. Food Chemistry, 254, 55-63.

Awika, J. M. (2011). Major cereal grains production and use around the world. Advances in cereal science: Implications to food processing and health promotion (pp. 1-13). Washington, DC: ACS Symposium Series; American Chemical Society.

Bailey, R. L., Fulgoni, V. L., Keast, D. R., Lentino, C. V., \& Dwyer, J. T. (2012). Do dietary supplements improve micronutrient sufficiency in children and adolescents? Journal of Pediatrics, 161, 837-842.

Barbosa, T. N. N., Taddei, J. A. A. C., Palma, D., Ancona-Lopez, F., \& Braga, J. A. P. (2012). Double-blind randomized controlled trial of rolls fortified with microencapsulated iron. Revista da Associação Médica Brasileira, 58, 118-124.

Benjakul, S., \& Karnjanapratum, S. (2018). Characteristics and nutritional value of whole wheat cracker fortified with tuna bone bio-calcium powder. Food Chemistry, 259, 181.

Berner, L. A., Keast, D. R., Bailey, R. L., \& Dwyer, J. T. (2014). Fortified foods are major contributors to nutrient intakes in diets of US children and adolescents. Journal of the Academy of Nutrition and Dietetics, 114, 1009-1022.

Berry, R. J., Bailey, L., Mulinare, J., Bower, C., \& Dary, O. (2010). Fortification of flour with folic acid. Food and Nutrition Bulletin, 31, 22-35.

Bilgi Boyaci, B., Han, J. Y., Masatcioglu, M. T., Yalcin, E., Celik, S., Ryu, G. H., \& Koksel, H. (2012). Effects of cold extrusion process on thiamine and riboflavin contents of fortified corn extrudates. Food Chemistry, 132, 2165-2170.

Bishai, D., \& Nalubola, R. (2002). The history of food fortification in the United States: Its relevance for current fortification efforts in developing countries. JSTOR - Economic Development and Cultural Change, 51, 37-53.

Black, R. E., Victora, C. G., Walker, S. P., Bhutta, Z. A., Christian, P., De Onis, M., \& Ezzati, M. (2013). Maternal and child undernutrition and overweight in low-income and middle-income countries. The Lancet, 382, 427-451.

Blanco-rojo, R., \& Vaquero, M. P. (2019). Iron bioavailability from food fortification to precision nutrition. A review. Innovative Food Science and Emerging Technologies, 51, 126-138.

Blumfield, M. L., Hure, A. J., Macdonald-wicks, L., Smith, R., \& Collins, C. E. (2013), Micronutrient intakes during pregnancy in developed countries: Systematic review and meta-analysis. Nutrition Reviews, 71, 118-132.

BNF (2019). Minerals and trace elements. Retrieved February 27, 2019, from https:// www.nutrition.org.uk/nutritionscience/nutrients-food-and-ingredients/mineralsand-trace-elements.html? showall $=1$ \&limitstart $=$.

Bolarinwa, I. F., Aruna, T. E., \& Raji, A. O. (2017). Nutritive value and acceptability of bread fortified with moringa seed powder. Journal of the Saudi Society of Agricultural Sciences, 1-6.

Bolarinwa, I. F., Aruna, T. E., \& Raji, A. O. (2019). Nutritive value and acceptability of bread fortified with moringa seed powder. Journal of the Saudi Society of Agricultural Sciences, 18, 195-200.

Bryszewska, M. A., Tomás-Cobos, L., Gallego, E., Villalba, M. P., Rivera, D., Taneyo Saa, D. L., \& Gianotti, A. (2019). In vitro bioaccessibility and bioavailability of iron from breads fortified with microencapsulated iron. LWT - Food Science and Technology, 99, 431-437.

Butt, M. S., Arshad, M. U., Alam, M. S., \& Nadeem, M. T. (2007). Bioavailability and storage stability of vitamin A fortificant (retinyl acetate) in fortified cookies. Food Research International, 40, 1212-1219.

Buzzo, M. L., Carvalho, F. M. H., Tiglea, P., de Arauz, L. J., Arakaki, E. E. K., \& Matsuzaki, R. (2012). Monitoring the wheat and corn flours enriched with iron. Revista do Instituto Adolfo Lutz, 71, 645-649.

Cardoso, R. V. C., Fernandes, Â., Heleno, S. A., Rodrigues, P., Gonzaléz-Paramás, A. M., Barros, L., \& Ferreira, I. C. F. R. (2019). Physicochemical characterization and microbiology of wheat and rye flours. Food Chemistry, 280, 123-129.

Cardwell, G., Bornman, J. F., James, A. P., \& Black, L. J. (2018). A review of mushrooms as a potential source of dietary vitamin D. Nutrients, 10, 1-11.

Carena, M. J. (2009). Handbook of plant breeding cereal. Fargo, ND, USA: Springer.

Chaudhari, P. D. N., Wandhekar, S. S., Shaikh, A. A. \& Devkatte, A. N. (2018). Preparation and characterization of cookies prepared from wheat flour fortified with mushroom (PleurotusSajorcaju) and spiced with cardamom. International Journal of Research and Analytical Review, 5, 386-389.

Chauhan, D., Kumar, K., Kumar, S., \& Kumar, H. (2018). Effect of incorporation of oat flour on nutritional and organoleptic characteristics of bread and noodles. Current Research in Nutrition and Food Science Journal, 6, 148-156.

Chiplonkar, S. A., Tarwadi, K. V., Kavedia, R. B., Mengale, S. S., Paknikar, K. M., \& Agte,
V. V. (1999). Fortification of vegetarian diets for increasing bioavailable iron density using green leafy vegetables. Food Research International, 32, 169-174.

Condé, V. F., Oliveira, J. E. Z., \& Oliveira, D. M. F. (2017). Farinha De Cogumelo Pleurotus Ostreatus (Hiratake) Enriquecido Em Ferro. Ciência e Natura, 39, 01.

Danza, A., Mastromatteo, M., Cozzolino, F., Lecce, L., Lampignano, V., Laverse, J., \& Del Nobile, M. A. (2014). Processing and characterization of durum wheat bread enriched with antioxidant from yellow pepper flour. LWT - Food Science and Technology, 59, 479-485.

Das, J. K., Salam, R. A., Kumar, R., \& Bhutta, Z. A. (2013). Micronutrient fortification of food and its impact on woman and child health: A systematic review. Systematic Reviews, 2, 1-24.

Das, J. K., Salam, R. A., Kumar, R., Lassi, Z. S., \& Bhutta, Z. A. (2014). Food fortification with multiple micronutrients: Impact on health outcomes (protocol). Cochrane Database of Systematic Reviews, 1-11.

Datta, M., \& Vitolins, M. Z. (2016). Food fortification and supplement use - are there health. Food Science \& Nutrition, 56, 2149-2159.

Del Pino-García, R., Rico, D., \& Martín-Diana, A. B. (2018). Evaluation of bioactive properties of Vicia narbonensis L. as potential flour ingredient for gluten-free food industry. Journal of Functional Foods, 47, 172-183.

Dwyer, J. T., Wiemer, K. L., Dary, O., Keen, C. L., King, J. C., Miller, K. B., ... Bailey, R. L. (2015). Fortification and health: Challenges and opportunities. Advances in Nutrition, 6, 124-131.

EFSA Panel on Dietetic Products Nutrition and Allergies (NDA) (2011). Scientific opinion on the substantiation of health claims related to: Dairy products (ID 1140, 1141, 1191 ), raw or processed food products of animal origin, plus bread and panification products (ID 1193, 1194), herbal yeast plasmolysate (ID 1815, 1816), apple polyphenols (ID 2713), rye flour (ID 1266), tomato juice (ID 1202), whey protein and alphalactalbumin (ID 424, 430, 432, 725, 1433), "brocco shoots", "broccoli sprout powder" and "Brassica oleracea var. italica (broccoli)" (ID 1362, 1481, 2844, 2845) EFSA Journal, 9, 33.

Emaleku, S. A., Omueti, O. D., \& Emaleku, G. O. (2018). Talinum triangulare whole wheat meal fortified with soy flour consumed with Talinum triangulare (gbure) soup glycemic index and the test human subjects' lipid profiles. Diabetes and Metabolic Syndrome: Clinical Research and Reviews, 12, 831-837.

Enzama, W., Afidra, R., Johnson, Q., \& Verster, A. (2017). Africa maize fortification strategy 2017 - 2026. Smarter Futures, 7-21.

Erukainure, O. L., Ebuehi, O. A. T., Adeboyejo, F. O., Aliyu, M., \& Elemo, G. N. (2013). Hematological and biochemical changes in diabetic rats fed with fiber-enriched cake. Journal of Acute Medicine, 3, 39-44.

Esteki, M., Regueiro, J., \& Simal-Gándara, J. (2019). Tackling fraudsters with global strategies to expose fraud in the food chain. Comprehensive Reviews in Food Science and Food Safety, 18, 425-440.

FAO (2017). The future of food and agriculture - trends and challenges. Rome.

FAO \& WHO (2015). General principles for the addition of essential nutrients to foods CAC/GL 9-1987, 49 §. CODEX ALIMENTARIUS International Food Standards.

FAO \& WTO (2017). TRADE AND FOOD STANDARDS. Food and agriculture Organization of the United Nations and the World Trade Organization. Retrieved from https:// www.wto.org/english/res_e/booksp_e/tradefoodfao17_e.pdf.

FAO, IFAD, UNICEF, WFP, \& WHO (2018). The state of food security and nutrition in the world 2018. Building climate resilience for food security and nutrition. Rome.

Fares, C., \& Menga, V. (2012). Effects of toasting on the carbohydrate profile and antioxidant properties of chickpea (Cicer arietinum L.) flour added to durum wheat pasta. Food Chemistry, 131, 1140-1148.

Farhat, G., Lees, E., Macdonald-Clarke, C., \& Amirabdollahian, F. (2019). Inadequacies of micronutrient intake in normal weight and overweight young adults aged 18-25 years: A cross-sectional study. Public Health, 167, 70-77.

FFI (2016). Say hello to a fortified future. Retrieved from http://ffinetwork.org/about/ stay informed/publications/documents/FFI2016Review.pdf.

FFI (2018). Food fortification initiative. 15 years of partnering for success. Atlanta, USA Retrieved from http://ffinetwork.org/about/stay_informed/publications/ documents/FFI2017Review.pdf.

FFI (2019a). Country profiles - mandatory or voluntary fortification. Retrieved March 19, 2019, from http://www.ffinetwork.org/country_profiles/index.php.

FFI (2019b). Flour millers toolkit for fortification. Retrieved February 15, 2019, from http://www.ffinetwork.org/implement/toolkit.html.

FFI (2019c). Global progress of industrially milled cereal grains- food fortification initiative. Retrieved January 31, 2019, from http://www.ffinetwork.org/global progress/index.php.

FFI (2019d). Implementing maize flour fortification- food fortification initiative. Retrieved February 22, 2019, from http://www.ffinetwork.org/implement/Maize. html.

FFI (2019e). Resources for implementing rice fortification. Retrieved February 17, 2019, from http://www.ffinetwork.org/implement/Rice.html.

Forsman, C., Milani, P., Schondebare, J. A., Matthias, D., \& Guyondet, C. (2014). Rice fortification: A comparative analysis in mandated settings. Annals of the New York Academy of Sciences, 1324, 67-81.

Fuckerer, K., Hensel, O., \& Schmitt, J. J. (2015). Volume and texture of Brown Rye bread fortified with different cellulose fibres length. Journal of Food and Nutrition Research, $3,637-640$.

Fuckerer, K., Hensel, O., \& Schmitt, J. J. (2016). Rye bread fortified with cellulose and its acceptance by elderlies in nursing homes and young adults. Journal of Food Studies, 5, $1-11$.

Garrod, M. G., Buchholz, B. A., Miller, J. W., Haack, K. W., Green, R., \& Allen, L. H (2019). Vitamin B12 added as a fortificant to flour retains high bioavailability when baked in bread. Nuclear Instruments and Methods in Physics Research B, 438, 136-140.

Gawlik-Dziki, U., Dziki, D., Swieca, M., Seczyk, Ł., Rozyło, R., \& Szymanowska, U. (2015) 
Bread enriched with Chenopodium quinoa leaves powder - The procedures for assessing the fortification efficiency. LWT - Food Science and Technology, 62, $1226-1234$.

GFDx (2019). Map: Number of Nutrients - Global Fortification Data Exchange | GFDx. Retrieved February 1, 2019, from https://fortificationdata.org/map-number-ofnutrients/\#.

Gibson, R. S., \& Hotz, C. (2002). Dietary diversification/modification strategies to enhance micronutrient content and bioavailability of diets in developing countries. British Journal of Nutrition, 85, 159-166.

Gigante, D. P., \& Victora, C. G. (2007). Effect of iron fortifi cation of flour on anemia in preschool children in Pelotas, Brazil. Revista de Saúde Pública, 41, 539-548.

Giménez, M. A., Drago, S. R., Bassett, M. N., Lobo, M. O., \& Sammán, N. C. (2016). Nutritional improvement of corn pasta-like product with broad bean (Vicia faba) and quinoa (Chenopodium quinoa). Food Chemistry, 199, 150-156.

Grossmann, I., \& Koehler, P. (2016). Fractionation-reconstitution studies to determine the functional properties of rye flour constituents. Journal of Cereal Science, 70, 1-8.

Gujska, E., \& Majewska, K. (2005). Effect of baking process on added folic acid and endogenous folates stability in wheat and rye breads. Plant Foods for Human Nutrition, $60,37-42$.

Hansen, M., Bæch, S. B., Thomsen, A. D., Tetens, I., \& Sandström, B. (2005). Long-term intake of iron fortified wholemeal rye bread appears to benefit iron status of young women. Journal of Cereal Science, 42, 165-171.

Hemery, Y. M., Laillou, A., Fontan, L., Jallier, V., Moench-Pfanner, R., Berger, J., \& Avallone, S. (2018). Storage conditions and packaging greatly affects the stability of fortified wheat flour: Influence on vitamin A, iron, zinc, and oxidation. Food Chemistry, 240, 43-50.

Hennessy, Á., Walton, J., \& Flynn, A. (2013). The impact of voluntary food fortification on micronutrient intakes and status in European countries: A review. Proceedings of the Nutrition Society, 72, 433-440.

Hettiarachchi, M., Hilmers, D. C., Liyanage, C., \& Abrams, S. A. (2004). Na2EDTA enhances the absorption of Iron and zinc from fortified rice flour in Sri Lankan children. The Journal of Nutrition, 134, 3031-3036.

Igoumenidis, P. E., Lekka, E. G., \& Karathanos, V. T. (2016). Fortification of white milled rice with phytochemicals during cooking in aqueous extract of Mentha spicata leaves. An adsorption study. LWT - Food Science and Technology, 65, 589-596.

Ishara, J. R. M., Sila, D. N., Kenji, G. M., \& Buzera, A. K. (2018). Nutritional and func tional properties of mushroom (Agaricus bisporus \& Pleurotus ostreatus) and their blends with maize flour. American Journal of Food Science and Technology, 6, 33-41.

Izydorczyk, M. S., \& McMillan, T. (2019). Section 3: Fortification of flours and breads: Section section 3.2: Addition of macronutrients. In V. R. Preedy, \& R. R. Watson (Eds.). Flour and breads and their fortification in health and disease prevention (pp. 347363). (2nd ed.). USA: Elsevier/Academic Press.

Jakubczyk, A., Świeca, M., Gawlik-Dziki, U., \& Dziki, D. (2018). Nutritional potential and inhibitory activity of bread fortified with green coffee beans against enzymes involved in metabolic syndrome pathogenesis. LWT - Food Science and Technology, 95, $78-84$.

Jakubowska, D., \& Staniewska, K. (2015). Information on food fortification with bioactive compounds in observation and consumer studies. Polish Journal of Natural Science, 30, 307-318.

Jiang, T., Christian, P., Khatry, S. K., Wu, L., \& West, K. P. (2005). Community and international nutrition micronutrient deficiencies in early pregnancy are common, concurrent, and vary by season among rural Nepali pregnant women. Journal of Nutrition, 135.

Johnson, Q., Mannar, V., \& Ranum, P. (2004). Fortification handbook vitamin and mineral fortification of wheat flour and maize meal. In A. Wesley, \& P. Ranum (Eds.) The micronutrient initiative.

Jungjohann, S., Hafiz, A., \& Shehata, M. (2015). Review of the national wheat flour fortification program in Egypt - Assessing compliance of mills fortifying subsidized flour/Baladi bread with folate and iron and estimating consumption of fortified flour among women of reproductive age using HIECS data. European Journal of Nutrition \& Food Safety, 5.

Kaminski, T. A., da Silva, L. P., do Nascimento Júnior, A., \& Ferrão, T.d. S. (2011). Nutritional, technological and sensory attributes of rye pasta. Brazilian Journal of Food Technology, 14, 137-144.

Kumar, R., Xavier, K. A. M., Lekshmi, M., Balange, A., \& Gudipati, V. (2018). Fortification of extruded snacks with chitosan: Effects on techno functional and sensory quality. Carbohydrate Polymers, 194, 267-273.

Kurek, M. A., Wyrwisz, J., Karp, S., \& Wierzbicka, A. (2017). Particle size of dietary fiber preparation affects the bioaccessibility of selected vitamin B in fortified wheat bread. Journal of Cereal Science, 77, 166-171.

Li, M., \& Eastman, C. J. (2012). The changing epidemiology of iodine deficiency. Nature Reviews Endocrinology, 8, 434-440.

Liyanage, C., \& Hettiarachchi, M. (2011). Food fortification. Ceylon Medical Journal, 56, 124-127.

Lonnerdal, B. (2003). Genetically modified plants for improved trace element nutrition. Journal of Nutrition, 133, 1490-1493.

Looman, M., Schoenaker, D. A. J. M., Soedamah-Muthu, S. S., Mishra, G. D., Geelen, A., \& Feskens, E. J. M. (2019). Pre-pregnancy dietary micronutrient adequacy is associated with lower risk of developing gestational diabetes in Australian women. Nutrition Research, 62, 32-40.

Luthringer, C. L., Rowe, L. A., Vossenaar, M., \& Garretta, G. S. (2015). Regulatory monitoring of fortified foods: Identifying barriers and good practices. Global Health: Science and Practice, 3, 446-461.

Mahamud, M., Shirshir, R. I., \& Hasan, R. (2012). Fortification of wheat bread using mushroom powder. Bangladesh Research Publications Journal, 7, 60-68.

Marks, K. J., Luthringer, C. L., Ruth, L. J., Rowe, L. A., Khan, N. A., De-Regil, L., ...
Pachón, H. (2018). Review of grain fortification legislation, standards, and monitoring documents. Global Health: Science and Practice, 6, 354-369.

Marques, M. F., Marques, M. M., Xavier, E. R., \& Gregório, E. L. (2012). Fortificação de alimentos: uma alternativa para suprir as necessidades de micronutrientes no mundo contemporâneo. HU Revista, 38, 29-36.

McLean, E., de Benoist, B., \& Allen, L. H. (2008). Review of the magnitude of folate and vitamin B 12 deficiencies worldwide. Food and Nutrition Bulletin, 29, 38-51.

Moniz, E., Aguilera, Y., Casado, N., Benítez, V., Esteban, R. M., \& Mollá, E. (2018). Breads fortified with wholegrain cereals and seeds as source of antioxidant dietary fibre and other bioactive compounds. Journal of Cereal Science, 82, 113-120.

Monteiro, M. L. G., Mársico, E. T., Deliza, R., Castro, V. S., Mutz, Y. S., Soares Junior, M. S., ... Conte-Junior, C. A. (2019). Physicochemical and sensory characteristics of pasta enriched with fish (Oreochromis niloticus) waste flour. Lwt, 111, 751-758.

Montemurro, M., Pontonio, E., \& Rizzello, C. G. (2019). Section 4: Metabolic responses to flour and bread fortification. In V. R. Preedy, \& R. R. Watson (Eds.). Flour and breads and their fortification in health and disease prevention (pp. 453-464). (2nd ed.). USA: Elsevier/Academic Press.

Mounjouenpou, P., Ngono Eyenga, S. N. N., Kamsu, E. J., Bongseh Kari, P., Ehabe, E. E., \& Ndjouenkeu, R. (2018). Effect of fortification with baobab (Adansonia digitata L.)pulp flour on sensorial acceptability and nutrient composition of rice cookies. Scientific African, 1, 1-9.

Muhammad, A., Khan, M. R., Tareen, A. K., Fahad, S., Faiq, M., Qazi, I. M., ... Uddin, Z. (2016). Effect of calcium fortification on whole wheat flour based leavened and unleavened breads by utilizing food industrial wastes. Asian Journal of Chemistry, 29, 423-430.

Naves, M. M. V., Fernandes, D. C., Prado, C. M. M., \& Telxeira, L. S. M. (2007). Food fortification with egg shell powder as a calcium source. Ciencia E Tecnologia De Alimentos, 27, 99-103.

Nestel, P., \& Nalubola, R. (2002). Wheat flour fortification with iron - Part 1 - Guidelines for the development, implementation, monitoring, and evaluation of a program for wheat flour fortification with iron. Retrieved from http://www.a2zproject.org/pdf/1. pdf.

Nuria Mateo Ansón (2010). Bioactive compounds in whole grain wheat. Maastricht University.

Nutrition International (2019). Nutrition international's grain fortification programs. Retrieved February 3, 2019, from https://www.nutritionintl.org/what-we-do/byprograms/fortification/.

Oghbaei, M., \& Prakash, J. (2012). Bioaccessible nutrients and bioactive components from fortified products prepared using finger millet (Eleusine coracana). Science of Food and Agriculture, 92, 2281-2290.

Oluyimika, Y. A., Kruger, J., White, Z., \& Taylor, J. R. (2019). Comparison between foodto-food fortification of pearl millet porridge with moringa leaves and baobab fruit and with adding ascorbic and citric acid on iron, zinc and other mineral bioacces sibility. LWT - Food Science and Technology, 106, 92-97.

Orriss, G. D. (1998). Food fortification: Safety and legislation. Food and Nutrition Bulletin 19, 109-116.

Osendarp, S. J. M., Martinez, H., Garrett, G. S., Neufeld, L. M., De-regil, L. M., Vossenaar, M., \& Darnton-hill, I. (2018). Large-scale food fortification and biofortification in low- and middle-income countries: A review of programs, trends, challenges, and evidence gaps. Food and Nutrition Bulletin, 39, 315-331.

Oyeyinka, A. T., \& Oyeyinka, S. A. (2018). Moringa oleifera as a food fortificant: Recent trends and prospects. Journal of the Saudi Society of Agricultural Sciences, 17, 127-136.

Pacho, H., Spohrer, R., Mei, Z., \& Serdula, M. K. (2015). Evidence of the effectiveness of flour fortification programs on iron status and anemia: A systematic review. Nutrition Reviews, 73, 780-795.

Pachón, H., Stoltzfus, R. J., \& Glahn, R. P. (2008). Chicken thigh, chicken liver, and ironfortified wheat flour increase iron uptake in an in vitro digestion/Caco-2 cell model. Nutrition Research, 28, 851-858.

Páramo-Calderón, D. E., Aparicio-Saguilán, A., Aguirre-Cruz, A., Carrillo-Ahumada, J., Hernández-Uribe, J. P., Acevedo-Tello, S., \& Torruco-Uco, J. G. (2019). Tortilla added with Moringa oleifera flour: Physicochemical, texture properties and antioxidant capacity. LWT, 100, 409-415.

Pathak, P., Kapoor, S. K., Saxena, R., Kumar, A., \& Gupta, N. (2004). Prevalence of multiple micronutrient deficiencies amongst pregnant women in a rural area of Haryana. Indian Journal of Pediatrics, 71, 1007-1014.

de Pee, S. (2014). Proposing nutrients and nutrient levels for rice fortification. Annals of the New York Academy of Sciences, 1324, 55-66.

Peña-Rosas, J. P., Field, M. S., Burford, B. J., \& De-Regil, L. M. (2014). Wheat flour fortification with iron for reducing anaemia and improving iron status in populations. Cochrane Database of Systematic Reviews, 1-18.

Preedy, V. R., \& Watson, R. R. (2019). Flour and breads and their fortification in health and disease prevention (2nd ed.). USA: Elsevier/Academic Press.

Preedy, V. R., Watson, R. R., \& Patel, V. B. (2011). Flour and breads and their fortification in health and disease prevention (1st ed.). USA: Elsevier/Academic Press.

Prentice, A. M., Gershwin, M. E., Schaible, U. E., Keusch, G. T., Victora, C. G., \& Gordon, J. I. (2008). Review series personal perspective new challenges in studying nutritiondisease interactions in the developing world. Journal of Clinical Investigation, 188, 1322-1329.

Prodhan, U. K., Linkon, K. M. M. R., Al-Amin, M. F., \& Alam, M. J. (2015). Development and quality evaluation of mushroom (Pleurotus sajor-caju) enriched biscuits. Emirates Journal of Food and Agriculture, 27, 542-547.

Radziejewska, A., \& Chmurzynska, A. (2019). Folate and choline absorption and uptake: Their role in fetal development. Biochimie, 158, 10-19.

Ramakrishnan, U. (2002). Prevalence of micronutrient malnutrition worldwide. Nutrition Reviews, 60(May).

Ranum, P. (2001). Zinc enrichment of cereal staples. Food and Nutrition Bulletin, 22, 
$169-172$.

Rebellato, A. P., Bussi, J., Silva, J. G. S., Greiner, R., Steel, C. J., \& Pallone, J. A. L. (2017). Effect of different iron compounds on rheological and technological parameters as well as bioaccessibility of minerals in whole wheat bread. Food Research International, 94, 65-71.

Rebellato, A. P., Klein, B., Wagner, R., \& Lima Pallone, J. A. (2018). Fortification effects of different iron compounds on refined wheat flour stability. Journal of Cereal Science, $82,1-7$.

Redant, L., Buggenhout, J., Brijs, K., \& Delcour, J. A. (2017). Extractability and chromatographic separation of rye (Secale cereale L.) flour proteins. Journal of Cereal Science, 73, 68-75.

Reshmi, S. K., Sudha, M. L., \& Shashirekha, M. N. (2017). Starch digestibility and predicted glycemic index in the bread fortified with pomelo (Citrus maxima) fruit segments. Food Chemistry, 237, 957-965.

Ritu, G., \& Gupta, A. (2015). Fortification of foods with vitamin D in India. Journal of the American College of Nutrition, 34, 263-272.

Sadighi, J., Sheikholeslam, R., Mohammad, K., Pouraram, H., Abdollahi, Z., Samadpour, K., ... Naghavi, M. (2008). Flour fortification with iron: A mid-term evaluation. Public Health, 122, 313-321.

Salmean, Y. A., Zello, G. A., \& Dahl, W. J. (2013). Foods with added fiber improve stool frequency in individuals with chronic kidney disease with no impact on appetite or overall quality of life. BMC Research Notes, 6, 1-5.

Santos, L. M. P., \& Pereira, M. Z. (2007). The effect of folic acid fortification on the reduction of neural tube defects. Control, 23, 17-24.

Sasson, A. (2005). UNU-IAS report. Food and nutrition biotechnology achievements, prospects, and perceptions. Yokohama, Japan.

Serdula, M. (2010a). Maximizing the impact of flour fortification to improve vitamin and mineral nutrition in populations. Food and Nutrition Bulletin, 31, 86-93.

Serdula, M. (2010b). The opportunity of flour fortification: Building on the evidence to move forward. Food and Nutrition Bulletin, 31, 3-6.

Sharif, M. K., Rizvi, S. S. H., \& Paraman, I. (2014). Characterization of supercritical fluid extrusion processed rice-soy crisps fortified with micronutrients and soy protein. $L W T$ - Food Science and Technology, 56, 414-420.

Sheikholeslami, Z., Karimi, M., Komeili, H. R., \& Mahfouzi, M. (2018). A new mixed bread formula with improved physicochemical properties by using hull-less barley flour at the presence of guar gum and ascorbic acid. LWT - Food Science and Technology, 93, 628-633.

Škrbić, B., Milovac, S., Dodig, D., \& Filipčev, B. (2009). Effects of hull-less barley flour and flakes on bread nutritional composition and sensory properties. Food Chemistry, 115, 982-988.

Sonkar, S., \& Singh, A. (2015). Improvement in nutritional properties of product through fortification with aloe vera, mushroom and pearl millets. Plant Archives, 15, 795-800.

Spink, J. (2019). The current state of food fraud prevention: Overview and requirements to address "How to Start?" and "How Much is Enough?". Current Opinion in Food Science, 24, 1-9.

Sui, X., Zhang, Y., \& Zhou, W. (2016). Bread fortified with anthocyanin-rich extract from black rice as nutraceutical sources: Its quality attributes and in vitro digestibility. Food Chemistry, 196, 910-916.

Sulieman, A. A., Zhu, K. X., Peng, W., Hassan, H. A., Obadi, M., Siddeeg, A., \& Zhou, H. M. (2019). Rheological and quality characteristics of composite gluten-free dough and biscuits supplemented with fermented and unfermented Agaricus bisporus polysaccharide flour. Food Chemistry, 271, 193-203.

Towo, E., Mgoba, C., Ndossi, D. G., \& Kimboka, S. (2006). Effect of phytate and ironbinding phenolics on the content and availability of iron and zinc in micronutrients fortified cereal flours. African Journal of Food Agriculture Nutrition and Development, 6, $1-14$.

Tripathi, B., Chetana, \& Platel, K. (2010). Fortification of sorghum (Sorghum vulgare) and pearl millet (Pennisetum glaucum) flour with zinc. Journal of Trace Elements in Medicine and Biology, 24, 257-262.

Tripathi, B., \& Platel, K. (2010). Finger millet (Eleucine coracana) flour as a vehicle for fortification with zinc. Journal of Trace Elements in Medicine and Biology, 24, 46-51.

Tripathi, B., \& Platel, K. (2011). Iron fortification of finger millet (Eleucine coracana) flour with EDTA and folic acid as co-fortificants. Food Chemistry, 126, 537-542.

Tripathi, B., \& Platel, K. (2013). Feasibility in fortification of sorghum (Sorghum bicolor L. Moench) and pearl millet (Pennisetum glaucum) flour with iron. LWT - Food Science and Technology, 50, 220-225.

Tripathi, B., Platel, K., \& Srinivasan, K. (2012). Double fortification of sorghum (Sorghum bicolor L. Moench) and finger millet (Eleucine coracana L. Gaertn) flours with iron and zinc. Journal of Cereal Science, 55, 195-201.

Urade, R. (2019). Section 3: Fortification of flours and breads: Section section 3.2: Addition of macronutrients. In V. R. Preedy, \& R. R. Watson (Eds.). Flour and breads and their fortification in health and disease prevention (pp. 365-373). (2nd ed.). USA: Elsevier/Academic Press.

Verma, A. (2015). Food fortification: A complementary strategy for improving micronutrient malnutrition (MNM) status. Food Science Research Journal, 6, 381-389.

Vlaic, R. A., Mureşan, C. C., Muste, S., Mureşan, A., Muresan, V., Suharoschi, R., ... Mihai, M. (2019). Food engineering - food fortification through innovative technologies. Intech open (pp. 25)

Wahengbam, E. D., Das, A. J., Green, B. D., Shooter, J., \& Hazarika, M. K. (2019). Effect of iron and folic acid fortification on in vitro bioavailability and starch hydrolysis in ready-to-eat parboiled rice. Food Chemistry, 292, 39-46.

Whiting, S. J., Kohrt, W. M., Warren, M. P., Kraenzlin, M. I., \& Bonjour, J. P. (2016). Food fortification for bone health in adulthood: A scoping review. European Journal of Clinical Nutrition, 70, 1099-1105.

WHO (2000). The world health report 2000 health systems: Improving performance. World Health Organization.

WHO (2009). Recommendations for wheat and maize flour fortification. Geneva, Switzerland.

WHO (2013). WHO | Global database on the Implementation of Nutrition Action (GINA). Retrieved February 3, 2019, from https://www.who.int/nutrition/gina/en/.

WHO (2016). Who guideline: Fortification of maize flour and corn meal with vitamins and minerals. Geneva: World Health Organization.

WHO (2017). Nutrients. Retrieved February 27, 2019, from https://www.who.int/elena/ nutrient/en/.

WHO (2018a). Guideline: fortification of rice with vitamins and minerals as a public health strategy (World Health Organization, Ed.) Geneva: World Health Organization.

WHO (2018b). Map: number of nutrients - Global Fortification Data Exchange | GFDx. Retrieved March 19, 2019, from https://fortificationdata.org/map-number-ofnutrients/.

WHO \& FAO (2006). In L. Allen, B. de Benoist, O. Dary, \& R. Hurrell (Eds.), Guidelines on food fortification with micronutrients. World Health Organization and Food and Agricultural Organization of the United Nations. 